\title{
Uretero-arteriální píštěl
}

\author{
MUDr. Tomáš Lakomý', MUDr. Pavel Svoboda', MUDr. Jaroslav Tůma', MUDr. Jiří Toman² \\ 'Urologické oddělení Nemocnice Nové Město na Moravě \\ ${ }^{2}$ Chirurgické oddělení Nemocnice Nové Město na Moravě
}

Uretero-arteriální píštěl je vzácná, potencionálně život-ohrožující příčina krvácení do vývodných cest močových, manifestující se masivní hematurií. První případ, v souvislosti s tlakem ureterálního stentu, byl popsán v roce 1908 Moschowitzem. V následující kazuistice prezentujeme pacienta po operaci pro pokročilý nádor rekta s následným masivním krvácením do močových cest $v$ důsledku prítomnosti pravostranné ureteroilické píštěle diagnostikované až peroperačně v rámci revize pro neztišitelné krvácení do urotraktu.

Klíčová slova: uretero-arteriální pištěl, hematurie, kolorektální karcinom.

\section{Uretero-arterial fistula}

Uretero-arterial fistula is a rare, but potentionaly life-threatening cause of bleeding into the urinary tract, manifested by gross haematuria. The first case associated with pressure of ureteral stent was described by Moschowitz in 1908. In the next case report we present a patient after pelvic surgery, for an advanced colorectal cancer, followed by gross haematuria by the reason of the presence of uretero-iliac fistula, diagnosed up during surgery for immitigable bleeding into the urinary tract.

Key words: uretero-arterial fistula, haematuria, colorectal cancer.

\section{Úvod}

Uretero-arteriální píštěl je vzácná, potencionálně život-ohrožujicí príčina krvácení do vývodných cest močových, manifestující se masivní hematurií (1). První prípad krvácení z ilických arterií, v souvislosti s tlakem ureterálního stentu, byl popsán v roce 1908 Moschowitzem (2).

Vznik nefyziologické komunikace mezi močovodem a tepnou úzce souvisí s předcházející radikální chirurgickou léčbou, ozařováním oblasti malé pánve, katetrizací ureterů, a nebo kombinací uvedených faktorů. Vzhledem ke skutečnosti, že tyto píštěle většinou způsobují masivní krvácení, vyžadují rychlou diagnostiku a aktivní cílenou terapii.

\section{Kazuistika}

Muž, 72 let, byl dovezen vozem rychlé záchranné služby na urologickou ambulanci naší nemocnice pro bolesti v pravé lumbální krajině, makroskopickou hematurii a febrilie.

Anamnesticky je pacient na jiném pracovišti po abdominoperineální amputaci rekta s následnou reoperací a s peroperační lézí pravého ureteru. Operačnímu řešení predcházela neoadjuvantní chemoterapie. To vše pacient absolvoval pro pokročilý tumor rekta s metastázami do jater. Dle dostupné dokumentace pacient od vlastní operace podstoupil extramurálně následující instrumentální výkony a vyšetření: cystoskopii s ascendentní pyelografií vpravo, kde byl 5 cm kraniálně od vezikoureterální junkce popsán únik kontrastní látky do retroperitonea, byla mu založena perkutánní nefrostomie, zaveden ureterální stent a permanentní močový katétr. Za měsíc došlo k plánované extrakci stentu a byl proveden nefrostomogram, již bez popisovaného úniku kontrastní látky mimo dutý systém, nově však vyšetření ukazuje stop pasáže kontrastní látky ureterem vpravo v úrovni L5. Pro tento fakt byl ureterální stent zaveden zpět a pacient zatím zůstává na stentu i nefrostomii pro již odsouhlasenou onkologickou adjuvantní léčbu. Řešení ureterální obstrukce je plánováno až po ukončení terapie na onkologii. Dle dynamického scintigrafického vyšetření, provedeného v odstupu jednoho a půl měsíce, je podíl obou ledvin na celkové tubulární funkci vpravo $48 \%$, a vlevo $52 \%$, vlevo se známkami obstrukce a vpravo s hraniční drenáží.

Fyzikální vyšetření odhaluje sekundární hojení kožního defektu po laparotomii, dále kolostomii a punkční nefrostomii vpravo, ostatní nález je bez pozoruhodností. Na ambulanci byl zaveden močový katétr k objektivizaci hematurie. Městnání nebylo sonograficky prokázáno, při dolním pólu pravé ledviny se však zobrazuje nevelká neurčitá formace charakteru organizovaného koagula. Z nefrostomie byla 
vypláchnuta drobná koagula, nyní nemocný pocituje úlevu, ale hematurie trvá. Proto byla ještě za RTG kontroly vyměněna nefrostomie a následně byl pacient odeslán k hospitalizaci na naše urologické oddělení.

Vstupní hodnoty renálních funkcí jsou v normě, ostatní biochemický nález rovněž nevykazuje patologii. Pouze v krevním obraze je pokles na $10^{8} \mathrm{~g} / \mathrm{l}$ hemoglobinu a 3,94 $\times 10^{12} / \mathrm{l}$ erytrocytů, bez leukocytózy. Pacient dostal intravenózní hemostyptickou terapii a byl mu vyměněn ucpaný močový katétr za 20 Charr. Pro trvající hematurii bylo doplněno kontrastní CT vyšetření, kde rentgenolog popsal 70\% stenózu arteria renalis I.dx. a hypoperfundovaný okrsek dorzálního rtu střední třetiny pravé ledviny, suspektní z ischemie, stent i nefrostomie ve správném postavení, kalichopánvičkový systém bez dilatace a močový měchýr mohutně vyplněn koaguly. Pro následný výrazný pokles v krevním obraze byly nemocnému podány 2 erymasy a 1 čerstvě zmražená plazma a opět vyměněna koaguly ucpaná nefrostomie. Na základě CT vyšetření byl pacient indikován k cystoskopické toaletě močového měchýře. Po evakuaci koagul byl vpravo identifikován distální pigtail stentu, v typickém postavení. Podél stentu ční z pravého ústí do měchýře hadovité koagulum, které bylo rovněž odstraněno. Následně se stav pacienta vcelku stabilizoval.

O sedm dní později se však pacientovi náhle udělalo slabo, pravá nefrostomie výrazně obtekla čerstvou krví a tou se rychle naplnil i nefrostomický sáček. Krev se v sáčku inned sráží a nelze vypustit. Nefrostomie byla okamžitě zaklemována, tonometr ukazuje TK 80/60 torr se 110 pulzy za minutu. Pacient byl bezprostředně zajištěn infuzí geloplazmy, kyslíkovou maskou a statimově nakřriženými 5 TU EBR a 2 plasmami. Vzápětí nemocný odjíždí na sál k otevřené operační revizi pro podezření na krvácení z punkčního kanálu nefrostomického drénu.

Operace byla započata cystoskopií. Z močového měchýře byla opět vypláchnuta četná koagula, z pravého ústí ční v nezměněné poloze stent. Stent byl volně extrahován a následně je z pravého ústí patrno silné čerstvé krvácení. Na základě tohoto bylo opět usouzeno na zdroj krvácení v punkčním kanálu nefrostomie a proto byla provedena salvage nefrektomie. Po ošetření a podvazu pravého ureteru však jeho pahýl pulzuje. Vyvstalo tedy klinické podezření na prítomnost uretero-arteriální píštěle. Ureter byl postupně vypreparován až k arteria iliaca externa dextra, kde jsou prítomné výrazné fibrotické změny a pevná fixace močovodu k tepně. Při další preparaci dochází k tangencionálnímu otevření arterie a ozřejmení píštěle. Tepna byla více uvolněna a kraniálně na ni naložena cévní svorka. Sutura defektu v tepně však není pro četné ateromatické pláty možná. $V$ této fázi byl privvolán chirurg, který provádí další deliberaci tepny, extrahuje pláty z jejího lumina a uzavírá defekt. Operaci ukončujeme suturou rány po jednotlivých anatomických vrstvách.

Pulzace jsou bezprostředně po operaci na pravé dolní končetině oslabené, ale hmatné. Pacient byl následně předán k pooperační péči na anesteziologicko resuscitační oddělení naší nemocnice. Večer po operaci ale byla diagnostikována ischemie pravé dolní končetiny, kdy CT angiografie odhaluje difuzní sklerotické změny tepen a uzávěr arteria iliaca communis dextra približně $2 \mathrm{~cm}$ pod bifurkací.

Ihned proběhla konzultace vyššího pracoviště, kam byl pacient ještě ten večer převezen k provedení zkříženého levo-pravého bypassu pravé společné ilické tepny.

Pacient se vrací 5. den po cévní rekonstrukční operaci zpět na naše pracoviště a po doléčení byl propuštěn, zcela soběstačný, do domácí péče.

\section{Diskuze}

Arterio-ureterální píštěle jsou vzácné. Podezření na ně by mělo vyvstat u pacientů s masivní hematurií po rozsáhlejších onkologických pánevních operacích, po prodělané radioterapii a dále pokud má pacient v anamnéze endoskopickou instrumentaci v horních močových cestách, např́klad opakovaný stenting. Diagnostickou metodou volby je kontrastní CT vyšetření, které v ideálním prípadě píštěl odhalí, a to v podobě úniku kontrastní látky. Elegantním řešením jsou pak endovaskulární techniky, nebo otevřená operační revize.

$\checkmark$ našem prípadě však preoperačně přesná diagnóza, navzdory provedenému kontrastnímu CT, známá nebyla. To potvrzuje skutečnost obtížné detekce tohoto typu pištělí.

Arterio-ureterální pištěle většinou vznikají sekundárně, za prítomnosti predisponujících faktorů, jako předchozí pánevní operace (3), dlouhodobá katetrizace močovodu ureterálním stentem (4), ozáření malé pánve (1, 3) a aneurysma ilické tepny (5). Právě ilické tepny představují nejčastěji postižené arterie (6). Spontánní arterio-ureterální píštěl, bez předcházející operace, endoskopické intervence či prítomnosti cévního aneuryzmatu, zatím nebyla zaznamenána (7). Všechny výše zmíněné rizikové faktory vedou na straně močovodu k periureterální fibróze a jeho devaskularizaci. $V$ alterovaném terénu vzniká na podkladě přenesených pulzací z ilické tepny, v místě křížení s ureterem, otlaková nekróza. Následně intraluminálně uložený double J stent napomáhá erozi do adherující arterie. Radioterapie pak na straně tepny ichemizuje její vasa vasorum, a tím napomáhá vzniku pištěle. Stent dále funguje jako chlopeň, částečně či úplně obturující vzniklou píštěl. To vysvětluje intermitentní hematurii. Při odstranění stentu většinou dojde k obnovení krvácení (4).

Správná preoperační diagnóza arterio-ureterální píštěle je obtí̌ná z několika důvodů. Pouhá arteriografie většinou selhává právě pro intermitentní krvácení. Extrakce ureterálního stentu může uvolnit koagulum v místě píštěle a vyvolat tak krvácení a usnadnit její odhalení právě pomocí arteriografie. Ureteropyelografie většinou zobrazí dilataci močovodu a kalichopánvičkového systému s defekty v náplni na podkladě koagul, ale neřekne nám nic o zdroji krvácení (1, 4). Cystoskopicky můžeme vyloučit př́činu krvácení v močovém měchýři, detekovat hematuri z prrislušného močovodu, ale opět ne príčinu. Nejvíce informací nám poskytne CT vyšetření, které zobrazí vztah distendovaného a krevními koaguly naplněného močovodu s adherující ilickou tepnou, doplněné angiografií (8). Vzhledem k obtížnosti preoperační detekce arterio-ureterální píštěle bychom na tuto možnost měli $\checkmark$ rámci diferenciální diagnostiky intermitentní masivní hematurie vždy pomýšlet.

Léčba je v první řadě orientována na arteriální část píštěle. Izolace tepny a uzavření defektu okamžitě zastaví krvácení (1). Pokud je stěna tepny v dobrém stavu, tak je sutura nástěnného defektu dostačující, ale $v$ případě masivního postižení cév aterosklerotickými pláty je třeba náročnější cévní operace s provedením extraanatomického cévního bypassu tak, aby nebyla př́slušná dolní končetina ohrožena ischemií (1). Další možností jsou endovaskulární stenty (9). Močovod je následně ošetřen suturou a zavedením ureterálního stentu. Pokud není defekt 


\section{| SDĚLENÍ Z PRAXE}

URETERO-ARTERIÁLNÍPIŚTTĚL

ve stěně močovodu př́liš velký, postačuje pouze stent (1), který je ponechán do zhojení defektu, optimálně několik měsíců (9).

\section{Závěr}

Cévní komplikace obecně představují závažné stavy, které mohou být důsledkem terapie různých, zvláště pak onkologických, onemocnění. Na prítomnost arterio - urete-

\section{LITERATURA}

1. Quillin S, Darcy M, Picus D. Angiographic evaluation and therapy of uretero-arterial fistulas. AJR Am J Roentgenol 1994; 162: 873-878., dostupný také na http://www.ncbi.n/m.nih. gov/pubmed/8141010.

2. Moschowitz AV. IX. simultaneous ligation of both external iliac arteries for secondary hemorrhage. Ann Surg 1908; 48(6): 872-825, dostupný také na http://www.ncbi.nlm.nih. gov/pubmed/17862274.

3. Dervanian P, Castaigne D, Travagli JP, et al. Arterio.ureteral fistula after extendend resection of pelvic tumors: report of three cases and review of literature. Ann Vasc Surg 1992; 6: 362-369, dostupný také na http://www.annalsofvascularsur- rální píštěle, jako možnou přičinu recidivující a různě silné hematurie, bychom měli pomýšlet u pacientů, kteří anamnesticky podstoupili ozáření malé pánve, byli radikálně operováni pro nádor v malé pánvi, mají dlouhodobě zavedený ureterální stent, anebo při kombinaci výše zmíněných faktorů.

Diagnostika a léčba arterio - ureterálních pištělí vyžaduje rychlý a mezioborový prístup

gery.com/article/S0890-5096(06)60570-0.

4. Zweers H, Van Driel M, Mensink H. Iliac artery-ureteral fistula associated with an indwelling ureteral stent. Urol Int 1991; 46: 213-214, dostupný také na http://www.ncbi.nlm. nih.gov/pubmed/2053236.

5. Grime P, Wilmshurst C, Clyne C. Spontaneous iliac artery aneurysm-ureteric fistula. Eur J Vasc Surg 1989; 3: 455456, dostupný také na http://www.ncbi.nlm.nih.gov/pub$\mathrm{med} / 2806577$.

6. Hanuš T, Novák K, et al. Nemoci močovodu. Galén. Praha 2008: 111.

7. Rennick J, Link D, Palmer J. Spontaneous rupture of an mezi urology, radiology a cévními chirurgy. Pokud je fistula detekována kontrastním CT vyšetřením, pak elegantní a efektivní řešení představují časné endovaskulární techniky, pokud přesnou diagnózu neznáme, je nutná otevřená operační revize.

Autor prohlašuje, že zpracování článku nebylo podpořeno žádnou společností.

iliac artery aneurysma into an ureter. J Urol 1976; 116: 111113, dostupný také na http://www.ncbi.nlm.nih.gov/pubmed/933269.

8. Jafri Z, Farah J, Hollander T, Diokno A. Urographic and computed tomographic demonstration of uretero-arterial fistula. Urol Radiol 1987; 9: 47-49, dostupný také na http://www. ncbi.nlm.nih.gov/pubmed/3603891.

9. Kerns B, Darcy M, Bauman D, Allen B. Autologous vein-covered stent for the endovascular management of an iliac artery-ureteral fistula: case report and review of the literature. J Vasc Surg 1996; 24:680-686, dostupný také na http://www. ncbi.nlm.nih.gov/pubmed/8911417. 